\title{
Data Communications and Networking in IS Curriculum: Framework for the Class Project
}

\author{
Andrzej Tomasz Jarmoszko and Michael Gendron \\ Central Connecticut State University, New Britain, CT USA
}

armoszkoa@ccsu.edu and gendronm@ccsu.edu

\begin{abstract}
Both practitioners and academics have recognized the importance of Data Communications and Networking (DCN) in undergraduate and graduate Information Systems education. This is confirmed, in particular, by the content of IS' 97 and MSIS 2000 model curricula for degree programs in Information Systems (note IS'97.6 and MSIS2000.3). Experience shows that one of the most effective ways to teach Information Systems concepts is via the juxtaposition of theory and practice in the setting of a group class project. Yet, in contrast to other IS courses, there appears to be no established way to conduct the class project in a DCN course, particularly in relation to the methods of logical and physical network design, and cost/benefit evaluation of network implementation. Our research addresses this shortcoming through an attempt to synthesize the experience of IS programs, and through an effort to take that experience a step forward.
\end{abstract}

Keywords: IS'97.6, MSIS2000.3, class project, data communications, networking, network design

\section{Introduction}

Both practitioners and academics have recognized the importance of Data Communications and Networking (DCN) in undergraduate and graduate Information Systems education. This is confirmed, in particular, by the content of IS'97 and MSIS 2000 model curricula for degree programs in Information Systems (note IS'97.6 and MSIS2000.3). The information systems of today almost by definition contain a network component which may, at times, determine whether a system succeeds or fails. Yet to authors' best knowledge there is no established methodology for network design appropriate for IS curriculum.

Experience shows that one of the most effective ways to teach Information Systems concepts is via the juxtaposition of theory and practice in the setting of a group class project. This approach has often been utilized in Systems Analysis and Design courses in which groups of students work on the analysis, design and sometimes implementation of an information system. In DCN courses, however, there appears to be no established way to conduct the class project.

In this paper we begin to address both shortcomings by proposing a framework for a DCN group project and by suggesting elements of network design methodology.

Material published as part of these proceedings, either on-line or in print, is copyrighted by Informing Science. Permission to make digital or paper copy of part or all of these works for personal or classroom use is granted without fee provided that the copies are not made or distributed for profit or commercial advantage AND that copies 1) bear this notice in full and 2) give the full citation on the first page. It is permissible to abstract these works so long as credit is given. To copy in all other cases or to republish or to post on a server or to redistribute to lists requires specific permission from the publisher at publister@intormingscience.org

\section{Literature Review}

Review of relevant literature on subject of group projects and DCN courses has not produced any tangible results. Both issues are treated separately, though. There is a sizable body of sources on the topic of group project. Alie, Beam, \& Carey (1998) and Kolb (1999 postulate that an ability to work in 
groups can have a bearing on the competitiveness of firms and economies. This is particularly true in the age of decentralized decision-making in which the focus of activity tends to shift toward temporary groups of experts created to address specific problems. Johnson, Johnson, and Smith (1991) go so far as to say stated that knowledge and skills are of no use if they cannot be applied in interactions with other people.

To assist instructors with the organizing of group projects Young and Henquinet (2000) have developed a framework consisting of critical factors for the design of group projects. These factors are presented in Table 1.

\begin{tabular}{|l|l|}
\hline \multicolumn{1}{|c|}{ Critical Factor } & \multicolumn{1}{c|}{ Description } \\
\hline Fit & $\begin{array}{l}\text { Evaluating components consistent with objective(s) } \\
\text { Assigning weights to evaluation components }\end{array}$ \\
\hline Breadth & $\begin{array}{l}\text { Establishing specific and appropriate evaluation criteria } \\
\text { Using multiple evaluators } \\
\text { Using multiple evaluation points (summative and formative) }\end{array}$ \\
\hline $\begin{array}{l}\text { Instructional is- } \\
\text { sues }\end{array}$ & $\begin{array}{l}\text { Defining the task } \\
\text { "Selling" the benefits of using a group project } \\
\text { Communicating what will be evaluated and by whom } \\
\text { Determining the extent that that students' grades will be interdependent (group } \\
\text { vs. individual grade) } \\
\text { Teaching group process }\end{array}$ \\
\hline Efficacy & $\begin{array}{l}\text { Comparing learning outcomes to leaving objectives } \\
\text { Redesigning group project }\end{array}$ \\
\hline Table 1: Critical Factors in Group Project Design (Young and Henquinet, 2000)
\end{tabular}

There are significantly fewer sources on the topic of DCN course content. Johnson, Stallard, and Tanner (1999) have polled both practitioners and academics on question of what should be taught in an undergraduate, senior-level DCN course and produced a ranking of topics. They have found considerable consensus within both groups, also on the question of exposing students to practical situations in network design.

\section{Proposed Framework}

The American Heritage Dictionary of the English Language defines the term framework as "a set of assumptions, concepts, values, and practices that constitutes a way of viewing reality." We believe that much of what a DCN group project should consist of can be contained within the factors of: objectives, scope, data environment, cost/benefit analysis, system design methodology, network design methodology, deliverables and evaluation.

The application of these factors may vary with the type of a DCN course offered. Undergraduate courses may place greater emphasis on the "language learning," of data communications and networking whereas graduate-level business courses may focus more managerial issues as applied to implementation of different options. 


\section{Objectives}

As is the case with most didactic activities, it is important to delineate a clear set of instructional objectives. In some cases group project objectives may be a subset of course objectives as a whole. In the general case, objectives should address specific behaviors, skills or tasks that the student would be able to engage in following the completion of the project.

A delineation of what is to be attained can help both students and the instructor to choose appropriate project execution methods and thereby set the stage for work to be done. Furthermore, if project objectives are clearly defined the task of student performance evaluation is a much easier undertaking. Finally, at the end of the project, outcomes can be compared to objectives to decide whether or not the project exercise had been properly designed. If not, corrective measures could be brought to bear.

\section{Scope}

Clearly, the scope of a DCN group project is directly related to content of the DCN course. Both graduate and undergraduate model curricula recommend that Local Area Network (LAN) and Wide Area Network (WAN) technologies be covered in DCN courses (Davis et al, 1997) (Gorgone et al, 2000). To complete the range of network types, the Metropolitan Area Network (MAN) could also be included. Although it is desirable from the standpoint of range of solution-types to include all possible network combinations, complexity of proposed solutions may limit the choice of scope.

\section{Data Environment}

In what data environment is the project going to take place? In an academic institution there appear to be three possible environments: 1) the environment of a real or fictitious case presented to students via some form of a written hand-out, 2) the environment of a client with some networking need who agrees to take part in the project in return for a delivered design document, and 3) any combination of the above two possibilities.

The decision between case-based or client-based projects hinges on the question of control vs. richness of the problem area. When using cases the instructor can significantly affect what students actually do in carrying out the project. This may be preferable when project course objectives call for acquisition of specific skills. Client-based projects, on the other hand, introduce students to a variety of real-life situations that would very difficult, if not impossible, to reproduce in classroom settings.

In choosing the data environment-type, issues pertaining to the location of the academic institution and composition of the student body may play a significant role. If there is little local industry to provide for project opportunities, the client-based method may not be feasible. Similarly, if students taking the DCN course work during the day and/or must commute to school it may not be realistic to expect much direct interaction with the client.

\section{Cost/Benefit Analysis}

If the DCN course is offered within a school of business then issues pertaining to tangible and intangible costs and benefits of network implementation should be addressed. As is the case with many information system projects, the cost part of the exercise is much easier to assess than the benefits side. This, however, is not an excuse for not trying. The only way to counter the practice of viewing IT as a cost center is to emphasize the revenue-generation or potential revenue-loss aspects of network implementation.

The extent to which students have been exposed to formal financial methods, it may be possible to require that Net Present Value, Return on Investment, and Break-Even Point be estimated as part of the exercise. 


\section{System Design Methodology}

Network is a system like any other and therefore it may be appropriate to use established IS methodologies for systems design. This is particularly true for projects, which have a more holistic approach to network design. While modeling data-flows may be appropriate to establish connectivity routes, focus on relationships between entities (entity-relationship diagrams) is likely to depend on the degree to which IS development is integrated with network design. In general the approach of Systems Development Life Cycle and logical and physical design can be adapted to fit the needs of a DCN group project.

\section{Network Design Methodology}

To the authors' best knowledge there is no established methodology for network design appropriate for IS curriculum. This may be a serious shortcoming of the way DCN courses are being taught today. The "assume-a-network" approach sometimes used in IS design may not be sufficient, given that today's information systems are complex entities in which the boundary between the network and the application is not easily identified.

Table 2 portrays one approach to physical design of a Local Area Network used in an undergraduate DCN course at Central Connecticut State University.

\begin{tabular}{|c|c|}
\hline Design Element & Description \\
\hline Nomenclature & $\begin{array}{l}\text { - Describe your nomenclature for switch, hub, patch panel, cable, server, } \\
\text { workstation, and other device Ids. } \\
\text { - Cabling list including cable ID, type, origination / destination, length in }\end{array}$ \\
\hline $\begin{array}{l}\text { Enterprise Level } \\
\text { design diagram }\end{array}$ & $\begin{array}{l}\text { - } \text { Each department and switching gear (switches/hubs) } \\
\text { - External Connectivity (e.g. WAN, INTERNET, INTRANET, EXTRA- } \\
\text { NET, VPN) } \\
\text { - Enterprise level devices and servers } \\
\quad \text { O Patch panels; Switches/cabinets; Hubs; Cabling; Printers; Worksta- } \\
\quad \text { tions; Departmental Servers; Other LAN devices } \\
\text { - Patch Panels/cabinets } \\
\text { - Narrative justifying why each technology/cabling type/hardware was cho- } \\
\text { sen - with all hardware cross-referenced by ID. }\end{array}$ \\
\hline $\begin{array}{l}\text { Design diagram for } \\
\text { each department }\end{array}$ & $\begin{array}{l}\text { - Patch panels; Switches/cabinets; Hubs; Cabling; Printers; Workstations; } \\
\text { Departmental Servers; Other LAN devices } \\
\text { - Narrative justifying why a particular technology/cabling type/hardware } \\
\text { was chosen - with all hardware cross-referenced by nomenclature. }\end{array}$ \\
\hline & Table 2: Elements of Physical LAN Design \\
\hline
\end{tabular}

\section{Deliverables}

The choice of deliverables for a DCN group project may or may not differ from deliverables in a standard Systems Analysis and Design course. Project proposal, requirements statement, walkthrough session, preliminary design and final design appear to be appropriate in the DCN setting as well. A formal final presentation involving all members of the group seems fitting to conclude the exercise. 


\section{Evaluation}

This issue to address in evaluating students' work is the number of evaluation sources. Young and Henquinet (2000) suggest that expanding the number of evaluators over and above the instructor may increase validity of assigned grade. Students are more likely to accept criticism if several evaluation sources are involved. To this end some form of peer and outside evaluation - engaging other group members and invited industry specialists - my be used.

\section{Survey Instrument}

We intend to survey the accessible population of DCN instructors on the proposed framework. At the time of this submission (March $15^{\text {th }}$ ) we have been running a web-based pilot survey located at: http://wwwsb.ccsu.edu/datacollect/den2/ The following summarizes the results of the pilot thus far:

- Even though only $20 \%$ of respondents currently use group projects in their DCN courses, $100 \%$ believe that group projects should be used as an instructional tool.

- The majority of respondents $(60 \%)$ believe that client-based group project is preferable to casebased group projects.

- The optimal number of students in a group project is 3-5.

- The weight of group project in assigning the final course grade falls in the range of $15 \%-50 \%$.

- Although for most currently this is not the case, $80 \%$ of respondents believe that the scope of the project should include the design of multiple network types (LAN,/MAN/WAN).

- Most $(80 \%)$ believe that the concepts of logical and physical design are useful or very useful.

- $60 \%$ believe that data flow diagrams are useful or very useful.

- $100 \%$ think that a methodology specifically aimed at logical network design would be useful or very useful in conducting a DCN group project.

- The majority of who currently use cases to establish the data environment for a DCN group project use no more than one case.

Once the pilot is complete we intend to revise the survey instrument and conduct the survey proper. The goal of the project is to test acceptance of our framework and to expand it based on feedback.

\section{Conclusions}

This is a report on research-in-progress on the topic of group projects in Data Communications and Networking courses. For those interested in using the group project tool within a DCN course we have proposed a framework based on the following factors: objectives, scope, data environment, cost/benefit analysis, system design methodology, network design methodology, deliverables and evaluation. We believe all of these factors need to be addressed to design a successful DCN group project. The framework will be tested via a web-based and mail-based survey of DCN instructors.

\section{References}

Alie, R. E., Beam, H. H., Carey, T. S. (1998). The use of teams in an undergraduate management program. Journal of Management Education, 22(6), 707-719.

Davis, G.B., Gorgone, J.T., Couger, J.D., Feinstein, D.L., Longenecker Jr., H.E. (1997). IS’97 Model Curriculum and Guidelines for Undergraduate Degree Programs in Information Systems. Data Base 28(1), pp. Bi-B94. 
Data Communications and Networking in IS Curriculum

Gorgone, J.T., Gray, P., Feinstein, D.L., Kasper, G.M, Luftman, J.N., Stohr, E.A., Valacich, J.S., Wigand, R.T., (2000). MSIS 2000 Model Curriculum and Guidelines for Graduate Degree Programs in Information Systems, accessed at hittp://cis.bentley.edu/TSA/pages/msis.htmm on March 11, 2002.

Johnson, D.W., Johnson, R.T., Smith, K.A. (1991). Active learning: Cooperation in the classroom. Edina, MN: Interaction Book Company.

Johnson, L.E., Stallard, J.J., Tanner, J.R., (1999) An empirical analysis of the content of the data communications course: Academics' and practitioners' perspectives. Information Technology, Learning, and Performance Journal (17:2), pp. 1-14.

Kolb, J. A. (1999). A project in small-group decision making. Journal of Management Education, 23(1), 71-79.

Young, C.B., Henquinet, J.A. (2000) A Conceptual Framework for Designing Group Projects. Journal of Education for Business, Sept/Oct2000, Vol. 76 Issue 1, p56, 5p

\section{Biographies}

Andrzej Tomasz Jarmoszko is currently Associate Professor in the Department of Management Information Systems, School of Business, Central Connecticut State University. His primary teaching areas are systems analysis and design and data communications and networking. Prior to joining CCSU faculty, Dr. Jarmoszko was Manager for Strategic Planning at a major mobile communications company in Central Europe. His research interests include Information Systems curriculum, aligning knowledge management with the strategy process, and strategic management in the communications industry.

Michael Gendron is also Associate Professor in the Department of Management Information Systems, School of Business, Central Connecticut State University. His research and teaching interests include Networking and Data Communications, Data and Information Quality, Internet Governance and Healthcare Informatics. Prior to joining CCSU faculty, Dr. Gendron was a telecommunications consultant for over 15 years. 